\title{
Refugees, Inequality, and Human Development
}

\author{
Anthony H. Richmond
}

\begin{abstract}
This paper examines the relation between refugee movements and indicators of income, education, and life expectancy in sending and receiving countries. Countries which score low on the Human Development Index are more likely to experience conflict giving rise to internal displacement and refugee movements. Wealthier countries accept the better educated for permanent settlement, while admitting lessskilled manual workers and asylum seekers on a temporary basis.
\end{abstract}

\section{Résumé}

Cet article examine les relations entre les mouvements de réfugiés et les indicateurs de revenus, l'éducation et l'espérance de vie dans les pays de départ et les pays d'accueil. Les pays avec un score bas sur l'Indice du développement humain ont le plus de probabilité de connaître des conflits provoquant des déplacements internes et des mouvements de réfugiés. Les pays plus riches acceptent les mieux éduqués pour l'établissement permanent, tout en admettant les travailleurs manuels moins éduqués ainsi que les demandeurs d'asile sur une base temporaire.

The huge disparities in living standards between the developed and less developed regions of the world account for much international migration, including refugee movements. There were an estimated 200 million international migrants in 2005. ${ }^{1}$ They accounted for approximately 12.9 per cent of the population of North America and 7.7 per cent in Europe, but less than 2 per cent of the population of Asia, Africa, and Latin America. ${ }^{2}$ While states reserve the right to control movement across borders and endeavour to prevent "illegal" immigration, migration occurs with or without legal sanction. People move from less developed to developed countries and regions, to perform menial or dirty work, supply field labour for agro-business, provide domestic services, or work in the sex trade. Many are victims of unscrupulous traffickers and smugglers. An estimated 800,000 people are trafficked annually. ${ }^{3}$ At the same time there is a "brain drain" of highly qualified professionals, including much-needed doctors and nurses. ${ }^{4}$ The term "much-needed" applies both to the sending and receiving countries. The net gains to wealthy countries raise serious ethical questions and issues concerning appropriate compensation that have been debated since the $1960 \mathrm{~s}^{5}$

The inequalities, which undoubtedly exist within wealthy countries, pale in significance when compared with the inequalities between them and the rest of the world. Poverty in Canada, Britain, and other OECD countries is a relative concept. It has no similarity to the absolute levels of deprivation experienced in the Third World. The world average gross national income per capita in 2001 was US $\$ 5,120$. The range was from $\$ 430$ in low-income countries, with an average of $\$ 26,510$ for the most advanced industrial countries. ${ }^{6}$ The Human Development Index (HDI) combines indicators of income, education, and life expectancy into a single measure of the quality of life in various countries and regions of the world. ${ }^{7}$ Table 1 summarizes the data. It indicates that Canada, with a score of .949 on the index, enjoys a very high quality of life, as do all the OECD countries, with an average score of .892. Developing countries' average score was .694 . The highest score, .963, was achieved by Norway and the lowest score was that of Niger at .281. Table 1 also shows the huge differences between wealthy countries and others, measured by gross domestic product per capita, life expectancy, and the gross enrolment ratio for primary, secondary, and tertiary education. As the UN report notes, variation in income, health, and education exist in every country, and inequalities associated with gender, race, and ethnicity interact and are reinforcing across generations. ${ }^{8}$ 
Table 1. Human Development Index 2003

\begin{tabular}{|l|c|c|c|c|}
\hline \multicolumn{1}{|c|}{ Region } & $\begin{array}{c}\text { Human } \\
\text { Development Index }\end{array}$ & $\begin{array}{c}\text { G.D.P. per capita: } \\
\text { US \$ }\end{array}$ & $\begin{array}{c}\text { Life Expectancy at } \\
\text { Birth }\end{array}$ & $\begin{array}{c}\text { Education } \\
\text { Enrolment ratio }\end{array}$ \\
\hline Canada & 0.949 & $\$ 30.677$ & 80.0 & 94 \\
\hline O.E.C.D. & 0.892 & $\$ 25,915$ & 77.7 & 63 \\
\hline Developing Countries & 0.694 & $\$ 4,359$ & 65.0 & 91 \\
\hline High HDI & 0.895 & $\$ 25,665$ & 78.0 & 66 \\
\hline Medium HDI & 0.718 & $\$ 4,474$ & 67.2 & 46 \\
\hline Low HDI & 0.486 & $\$ 1,046$ & 46.0 & 67 \\
\hline World & 0.741 & $\$ 8,229$ & 67.1 & \\
\hline
\end{tabular}

Source: UN Human Development Report, 2005.

There is a close connection between the incidence of violent conflict and low levels of income, and/or low scores on the Human Development Index. Nine out ten countries at the bottom of the Human Development Index have experienced violent conflict since $1990 .^{9}$ Afghanistan, in particular, has experienced both external and internal conflict, including invasion by the Soviet Union and, more recently, the United States and its allies, in the "war against terrorism." It is not surprising that Afghanistan has been the source of the largest concentration of refugees, mostly located in camps in Iran and Pakistan. Other major source countries for refugees in 2004 were Sudan, Burundi, Democratic Republic of the Congo (DRC), and Somalia. To these must be added an additional 5.4 million internally displaced persons worldwide. These include people escaping conflicts in Africa, Latin America, Asia, and the former Soviet Union.

When all those of concern to the UN High Commissioner for Refugees (UNHCR) are considered (including refugees in camps, asylum seekers, the internally displaced, and returnees), Asian countries carry the heaviest burden of relief, followed closely by Africa and the Middle East. In 2004 there were an estimated 9.24 million "Convention" refugees, and many externally and internally displaced persons. The UNHCR reported more than 19.2 million persons of concern to that agency in 2004. (To these must be added another 3.8 million Palestinians under the care of the United Nations Relief and Works Agency (UNRWA ). Even before the US-led war in Afghanistan that country was the largest single source of refugees in the world. In 2001 there were 3.6 million Afghan refugees mainly located in camps on the borders with Pakistan and Iran. That number declined as some were able to return. The UNHCR reported over two million Afghan refugees at the end of 2004.
With over one million refugees, mainly from Afghanistan, Iran had the largest number of persons of concern to the UNHCR in 2004 but, due to its oil revenues, it was better able to carry the burden than Pakistan, which had close to one million refugees in 2004. When the number of persons of concern to the UNHCR is considered in relation to the hostcountry capacity to support those in need (as measured by Gross Domestic Product per capita) the countries carrying the heaviest burden, between 1999 and 2003, were Pakistan, DRC, Tanzania, and Ethiopia. These and other countries that had responsibility for large numbers of persons of concern to the UNHCR are shown in Table 2. On the Human Development Index, they all scored below the average for developing countries as a whole.

In the decade 1994 to 2003, more advanced industrial countries accepted fewer than one million refugees previously recognized by the UNHCR. The number of asylum applications submitted in advanced industrial countries fluctuated yearly; it averaged over half a million annually in that decade. However, between 1994 and 2003, out of the over five million asylum claims made at borders, or after entry to wealthy countries, only 18 per cent received full Convention refugee status. A further 20 per cent were allowed to stay on humanitarian grounds or were given temporary protection. The acceptance rate in the European Union averaged 25 per cent. This compares with 46 per cent of those applying in Canada. ${ }^{10}$

The main countries of asylum for refugees in relatively wealthy countries are shown in Table 3. Relative to GDP per capita, Germany carried the heaviest burden. The United States and the Russian Federation had a large number of refugees and asylum seekers. Because of proximity to other African countries experiencing civil war and other conflicts, 
Table 2. Host Country Capacity to Support Those of Concern to the UNHCR: Ten Countries Carrying Heaviest Burden

(By GDP per capita and Human Development Index)

\begin{tabular}{|l|c|c|c|}
\hline \multicolumn{1}{|c|}{ Country of Asylum } & $\begin{array}{c}\text { Total Persons of } \\
\text { Concern, 2004 * }\end{array}$ & $\begin{array}{c}\text { Ratio of Refugees } \\
\text { (1999-2003) to } \\
\text { GDP per capita }\end{array}$ & $\begin{array}{c}\text { Human Development } \\
\text { Index }\end{array}$ \\
\hline Iran & $1,046,722$ & 989 & .736 \\
\hline Pakistan & 968,774 & 3,936 & .527 \\
\hline Sudan & 845,867 & 789 & .512 \\
\hline Tanzania & 602,256 & 2,544 & .418 \\
\hline Uganda & 252,382 & 950 & .508 \\
\hline Kenya & 249,310 & 583 & .474 \\
\hline D.R. Congo & 213,510 & 2,775 & .395 \\
\hline Zambia & 173,981 & 703 & .466 \\
\hline Guinea & 145,571 & 767 & .367 \\
\hline Ethiopia & 116,027 & 1,984 & \\
\hline
\end{tabular}

* Includes refugees, asylum seekers, internally displaced and returnees

Source: UNHCR Statistical Reports, 2004-2005, and UN Human Development Report, 2005.

Table 3. Host Country Capacity to Support Those of Concern to the UNHCR: Selected Advanced Industrial Countries

(By GDP per capita and Human Development Index)

\begin{tabular}{|l|c|c|c|}
\hline \multicolumn{1}{|c|}{ Country of Asylum } & $\begin{array}{c}\text { Total Persons of } \\
\text { Concern, 2004* }\end{array}$ & $\begin{array}{c}\text { Ratio of Refugees } \\
\text { (1999-2003) to GDP } \\
\text { per capita }\end{array}$ & $\begin{array}{c}\text { Human Development } \\
\text { Index: 2003 }\end{array}$ \\
\hline Germany & 973,392 & 39 & .930 \\
\hline United States & 684,564 & 14 & .944 \\
\hline Russian Federation & 664,552 & 12 & .795 \\
\hline United Kingdom & 298,854 & 8 & .939 \\
\hline Canada & 168,688 & 6 & .949 \\
\hline Netherlands & 155,257 & 6 & .943 \\
\hline France & 152,160 & 5 & .938 \\
\hline South Africa & 142,907 & 8 & .658 \\
\hline Sweden & 101,451 & 5 & .949 \\
\hline Australia & 688,498 & 3 & .955 \\
\hline
\end{tabular}

* Includes refugees and asylum seekers

Source: UNHCR Statistical Reports, 2004-2005; Human Development report, 2005. 
Table 4. Global Perspectives on Inequality at the Beginning of the 21st Century Human Development Index

\begin{tabular}{|l|c|c|c|c|}
\hline & $\begin{array}{c}\text { High HDI } \\
\mathbf{8 9 9 5}\end{array}$ & $\begin{array}{c}\text { Med HDI } \\
\mathbf{. 7 1 8}\end{array}$ & $\begin{array}{c}\text { Low HDI } \\
. \mathbf{4 8 6}\end{array}$ & $\begin{array}{c}\text { Total/Av. } \\
\mathbf{7 4 1}\end{array}$ \\
\hline Total population 2001 & 903 million & 2,328 million & 2,823 million & 6,054 million \\
\hline GDP per capita US dollars & $\$ 25,665.00$ & $\$ 4,471.00$ & $\$ 1,046.00$ & $\$ 8,229.00$ \\
\hline Armed conflicts in 2004 & 1 & 11 & 20 & 32 \\
\hline In 2004: No. of refugees from* & 0 & 2.7 million & 6.5 million & 9.2 million \\
\hline $\begin{array}{l}\text { No. of refugees directly resettled } \\
\text { 1994-2003 }\end{array}$ & 991,137 & & & 991,137 \\
\hline $\begin{array}{l}\text { No. of asylum seekers 1994-2003 } \\
\text { accepted ** }\end{array}$ & $\begin{array}{l}\text { 1.4 million } \\
\text { asylum claims } \\
\text { submitted }\end{array}$ \\
\hline
\end{tabular}

* Does not include Palestinians under UNRWA; or internally displaced, returnees and others under care of the UNHCR.

** Includes Convention status and other humanitarian grounds. An additional half million were given temporary protection Sources: UN Development agency; UNHCR; UN Population Division; Project Ploughshares .

South Africa received many asylum seekers, and scored relatively low on the HDI. When these advanced industrial countries are compared with the countries listed in Table 2, it is evident that they were not carrying a serious burden when measured in terms of GDP per capita. Furthermore, the majority of asylum seekers in industrialized countries do not come from the poorest countries. In 2004 the largest number of new and appeal asylum claims were filed by nationals of the Russian Federation $(35,200)$, Serbia and Montenegro $(30,900)$, China $(29,000)$, the DRC $(29,000)$, and Turkey $(27,000)$. The numbers reaching industrialized countries fell slightly after 2001, partly due to interdiction and deterrent measures adopted by Britain and some other countries. The largest number of new asylum claims in 2004 were received by France $(58,500)$, the UK $(40,200)$, Germany $(35,600)$, South Africa $(32,600)$, and the United States $(27,900) .{ }^{11}$

The global situation is summarized in Table 4. It shows the relation between scores on the Human Development Index and other variables, including the response of wealthier countries to the needs of refugees and asylum seekers at the beginning of the twenty-first century. The world's population of over six billion people is heavily concentrated in the poorer regions of the world, which also experience the majority of armed conflicts and persecutions that give rise to refugee movements and asylum seekers. In 1995 there were forty-four armed conflicts in thirty-nine states. The number declined to thirty-two conflicts in twenty-six states in 2004. Two-thirds of these states scored low (less than .500) in the
Human Development Index. With the exception of Israel, which scored .915 , the remaining states experiencing armed conflicts on their soil ranged from .508 to .795 on the HDI. As noted by the UN Human Development Report, armed conflict itself contributes to a decline in the level of human development and welfare.

Refugees and asylum applicants in industrialized countries are likely to experience exclusion from fundamental human rights and the benefits of a welfare society. The exclusion of refugees and asylum applicants recently reached dramatic and tragic proportions in the case of Australia's treatment of "boat people" escaping from Afghanistan and other Asian countries. Several ships were prevented from reaching Australian territory. Instead they were escorted to remote Pacific islands where the UNHCR processed their refugee claims, without any commitment from the Australian government that those deemed to be victims of persecution would be accepted. Asylum applicants who do succeed in reaching Australia are placed in remote camps under conditions that have given rise to hunger strikes, suicide, and other protests. It was reported in February 2004 that the Australian government paid Papua New Guinea $£ 300,000$ per month to detain one Palestinian refugee being kept in solitary confinement on Manus Island. ${ }^{12}$ These actions represent an exclusionist approach to refugees and asylum seekers which is at variance with the multicultural policies espoused by previous Australian governments. ${ }^{13}$ Interdiction is practised by most industrialized countries concerned with the question of 
human trafficking and the protection of borders. The United States endeavours to prevent Haitian and Cuban migrants from reaching its shores as well as to control access via its border with Mexico. ${ }^{14}$ In Europe, Spain and Italy intercept migrants travelling from Africa via the Mediterranean, while Britain operates its immigration rules extraterritorially to exclude Romany travellers and others. ${ }^{15}$

Even before the events of 11 September 2001, increased migration pressures, legal and illegal, led to a tightening of regulations in most developed countries, together with legislation designed to deter migration, interdict undocumented travellers, and reinforce border controls. New regulations penalize airlines, shipping companies, and truckers who are discovered to have carried, knowingly or unknowingly, passengers who do not have a legal right of entry. For example, Canada introduced Bill C11. This law increased the powers of immigration officers to refuse entry to Canada on grounds of criminality, security risk, or forged and inadequate identity documents. It imposed higher maximum penalties for human smuggling, and places the responsibility on airlines to identify and inform Canadian authorities regarding passengers who may be inadmissible to Canada. At the same time it left those genuinely in need of protection from persecution at greater risk When these immigration controls are combined with anti-terrorism measures there are direct threats to civil liberties. ${ }^{16}$

The victims of political and ethnic power struggles account for the large-scale movements of refugees that have occurred in eastern and central Europe, Africa, Asia, and Latin America. Developed countries in western Europe, North America, and Australasia are reluctant to give asylum to all those who flee persecution or seek to escape the economic and environmental disasters that occur in the wake of such conflicts. Many displaced persons, as well as socalled "economic migrants," are being denied protection, by a strict application and narrow interpretation of the Geneva Convention criteria for full refugee status. Since September 2001, even more restrictive measures have been adopted in the name of improved security.

Various practises are used by wealthier countries to manage and control population movements. They involve classifying people according to their perceived eligibility to enter, or remain in, a particular territory. This has been called a form of "global apartheid. ${ }^{17}$ The instruments for the enforcement of global apartheid are interdiction, passports, visas, residence permits, work permits, and denial of citizenship rights, including access to education, government-funded health and welfare services, etc. The forcible repatriation of refugees to so-called "safe third countries" is now standard practise, together with the deportation of "illegal" immigrants. These forms of state control of immigration are seen as a legitimate response to the destabilizing effects of largescale migration. They are indirectly discriminatory by "race" because the majority of refugees and asylum applicants come from, and are obliged to remain in, Third World countries. Only a few actually reach Europe and North America.

In contrast to the restrictions placed on asylum seekers and so-called "economic migrants," capital moves freely around the world and entrepreneurs with money to invest have little difficulty obtaining residence permits, official immigrant status, or even citizenship of the countries they wish to operate in. Special immigration programs for entrepreneurs, investors, and the highly qualified are examples of this. It is not so easy for those who bring only their labour, or who are deemed alien in language, culture, or religion. When not labelled "illegal" and imprisoned or deported, such workers find only low-paid employment in manual jobs, often clandestine employment below the minimum wage. Asylum seekers and so-called "economic migrants" are the new underclass, when they are not actually deported or refused entry altogether. From a global perspective there are various forms of exclusion, ranging from denial of entry to the country, through deportation, to refoulement (the expulsion of refugees who may face persecution, even ethnic cleansing, in their former country). ${ }^{18}$

\section{Conclusion}

Some people are fully incorporated into the advanced industrial economy of the emerging global system, while others are marginalized. Poverty is endemic in some regions of the world but the experience of deprivation is not confined to developing countries. Controls over the movement of people across national borders are designed to preserve absolute and relative advantage. While advanced industrial societies welcome immigrants who bring money or human capital, others are excluded even when there are political as well as economic reasons for their migration and humanitarian reasons for their admission.

Since 2001, and the terrorist attacks in the US, Spain, and Britain, security considerations have further limited freedom of movement between countries. When viewed from a global perspective Canada, and other advanced industrial societies, are in a privileged position. At the same time they are increasingly dependent upon immigration for demographic and economic reasons. Consequently, there is a profound ambivalence concerning the implications in relation to refugees, asylum seekers, and economic migrants. On the one hand, humanitarian concerns and obligations under UN conventions concerning refugees and human rights oblige wealthy countries to accept refugees and asylum seekers who are deemed to be genuine victims of persecution. On the other hand, so-called "economic migrants" are either exclud- 
ed altogether, or admitted on a temporary basis to perform the poorly paid heavy manual and service occupations that the indigenous population do not wish to undertake. The exceptions are immigrants with capital to invest, or human capital in the form of professional qualifications, which may or may not be recognized in the receiving country. Refugees and economic migrants alike experience discrimination in wealthy countries. However, the heaviest burden of care for the internally displaced and refugees rests on less developed countries in regions where armed conflicts have occurred.

\section{Notes}

1. Global Commission on International Migration (GCIM), Migration in an Interconnected World: New Directions for Action (Geneva: GCIM, 2005).

2. Ibid., 83.

3. Ibid., 85 .

4. D. Kapur and J. McHale, Give Us Your Best and Brightest: The Global Hunt for Talent and Its Impact on the Developing World (Washington, D.C.: Center for Global Development, 2005).

5. G. Beijer, "Selective Migration for and 'Brain Drain' from Latin America," International Migration 4, no. 1 (1966): 2840.

6. World Bank, Breaking the Conflict Trap: Civil War and Development Policy (Washington, D.C.: World Bank, 2003); World Bank, World Development Indicators (Washington, D.C.: World Bank, 2003).

7. UN Human Development Program, "International Cooperation at the Crossroads," in UN Human Development
Report 2005 (New York: U. Human Development Program, 2005).

8. Ibid.

9. Ibid

10. UNHCR, "Basic Facts," in Global Refugee Trends 2004 (Geneva: UNHCR, 2005).

11. UNHCR, Global Refugee Trends 2004 (Geneva: UNHCR, 2005).

12. D. Fickling, "Australia pays $£ 1.8$ million to hold a single refugee," The Guardian, February 12, 2004.

13. J. Howard, "Australia and the Interdiction of Asylum Seekers," Refuge 21, no.4 (2003): 35-50.

14. J. Morris, J., "American and Australian Interdiction Policies," Refuge 21, no. 4 (2003): 51-62.

15. A. Sianni, "Interception Practices in Europe and Their Implications," Refuge 21, no. 4 (2003): 25-34.

16. A. Macklin, "Borderline Security," in Essays on Canada's Anti-Terrorism Bill, ed. R.J. Daniels, P. Macklem, and K. Roach (Toronto: University of Toronto Press, 2001),

17. A.H. Richmond, Global Apartheid: Refugees, Racism and the New World Order (Don Mills, ON: Oxford University Press, 1994); A.H. Richmond, "Social Exclusion: Belonging and Not Belonging in the World System," Refuge 21, no. 1 (2002): 40-48.

18. A.H. Richmond, "Socio-Demographic Aspects of Globalization: Canadian Perspectives on Migration," Canadian Studies in Population 29, no. 1 (2002): 123-149.

Anthony H. Richmond is Emeritus Professor of Sociology and Senior Scholar, Centre for Refugee Studies, York University, Toronto. 